\title{
ANALYSIS OF THE USE OF LABOR FORCE IN A PATRIMONIAL ENTITY
}

\author{
Valentin PÎRVUȚ*, Alin HUSERAȘ** \\ *“Nicolae Bălcescu” Land Forces Academy Sibiu, Romania \\ **“Lucian Blaga" University, Sibiu, Romania \\ pirvut_v@yahoo.com, huseras.alin@gmail.com
}

\begin{abstract}
Under the conditions of the transition to a competitive economy, the human factor has a dominant role in the process of including the efficiency of the organization on a vibrating trajectory, hence the important significance of evaluating the performance of the personnel from the perspective of the utilization of human resources. Thus, it is fully justified to speak of the efficiency of the use of human resources as an essential component of the general concept of economic efficiency. If the efficiency of the use of human resources is sometimes reduced to the integral time of work in the specialized literature, the emphasis being placed on the quantitative side, a correction is demanded in the modern sense. The efficient use of human resources needs to keep pace with the qualitative aspect, which includes the totality of personnel operations: recruiting, selection, training, evaluation, promotion, social dialogue and motivational system.
\end{abstract}

\section{Keywords: structure, resource, efficiency, indicators, analysis}

\section{Introduction}

Human resources management represents the science and art of developing and implementing the personnel strategy and policy with a view to achieving the company's objectives with maximum efficiency.

The human resource is the element that decisively influences the entire activity of the enterprise, being the component that actively and creatively coordinates the use of the other categories of resources available to the company, namely the informational, material and financial resources. Moreover, human resources definitely influence the economic development of a country, which depends on the degree of professional training and dedication of the human resources [1].
The appropriate capitalization of human resources can bring substantial benefits at the enterprise level, and the inappropriate selection of employees can cause damage to the image of the enterprise and material loss as well.

Also, the human resources management aims to maintain a balance between the groups directly involved and those interested in the funtioning of the enterprise: owners, managers, employees, suppliers, etc. [2].

In the traditional theory of enterprise, employees were looked upon by the way in which they carried out certain preestabilitated operations, in a disciplined manner, put into motion technological machinery and devices, or accomplished some activities. That is why there emerged 
the concepts used unfortunately today of "labor force" or even "labor hand". What was of interest was their capacity to carry out the managers' decisions, according to the rules. The labor force concept was defined as being "the totality of physical and intellectual aptitudes that people use in the process of obtaining goods and services". This is how there emerged the division of work", especially in totalitarian regimes of marxist origin, into "productive labor" and "creators of of material goods" and "non-productive labor" and "non-productive labor" and "nonproductive personnel", who was associated, as a rule, with people who carried activities of an intellectual nature. Any action of labor force improvement directly aimed at developing the capacity to work well, more, to carry out several operations. The concept of "labor force" was always used in the singular and designated the ensemble, the mass. Never was it considered individually, with specific personality, needs, behavior and vision within the managers' objectives [3].

In the context of the competitive economy, the human factor dominates the organization in terms of its efficiency and the performance development gains a special importance from the point of view of the human factor.

This orientation in evaluation is generated by the fact that the human resource potential constitutes the creative, active and coordinating factor of economic activity, and its full capitalization is the main means of increasing economic efficiency.

Thus, at the enterprise level, the responsibility of knowing the mechanism of interests, contradictions between the organizational objectives and the aspirations of the staff must be assumed, the systematic practice of a system of common incentives having important effects on the success of the policies of human resources utilization.

\section{Indicators of the Labor Force Use}

Productivity of labor is the indicator that characterizes the degree of efficient utilization of human resources and is calculated by means of indicators in value expression or by means of indicators in physical expression. The level of labor productivity is expressed by the amount of products obtained in a unit of time, or by the labor cost of the unit that produces it. Correspondingly, the following methods should be outlined:

- direct method $\mathrm{W}=\mathrm{q} / \mathrm{T}$

- reverse method $\mathrm{t}=\mathrm{T} / \mathrm{q}$

in which: W,t - the level of labor productivity; $\mathrm{q}$ - the volume of production; $\mathrm{T}$ - the labor consumption in units of time.

Depending on the nature of the indicator, two types of productivity can be identified, calculated on the basis of value and physical indicators.

The average productivity $(\bar{W})$ is calculated with a value expression by means of the indicators : the turnover, the added value, the production made for sale, the sold production, the gross added value, having the following form:

$$
\bar{W}=\frac{P}{T}
$$

where: P - production with a value expression: turnover, added value; $\mathrm{T}$ - total consumption of labor time

or

$$
\bar{W}=\frac{T}{P} \times 1000
$$

For these reasons, $\bar{W}$ is included in the system of indicators of economic efficiency. 
We identify the following modalities of calculation of $\bar{W}$ with a value expression:

a. annual average productivity $(\bar{W} a)$ :

$$
\overline{W a}=\frac{P}{N p}
$$

where: $\mathrm{P}$ - production with a value expression; $\mathrm{Np}$ - annual average personnel. or:

$$
\bar{W} a=\frac{\bar{N} p}{P} \times 1000
$$

b. average daily productivity $(\bar{W} z)$ :

$$
\bar{W} z=\frac{P}{N p \times t z}
$$

where: $t z$ - labor time expressed in days spent by an employee in a year

or:

$$
\bar{W} z=\frac{\bar{N} p \times t z}{P} \times 1000
$$

c. average hourly productivity $(\overline{W h})$ :

$$
\bar{W} h=\frac{P}{N p \times t z \times t h}
$$

where: $N p \times t z \times t h$ - consumption of total time expressed in hours; th - daily labor time for 1 employee expressed in hours or:

$$
\bar{W} h=\frac{\bar{N} p \times t z \times t h}{P} \times 1000
$$

An important role $\mathrm{W}$ has in calculating the balance and efficiency correlations, that is:

$$
\mathrm{I}_{\mathrm{W}}>\mathrm{I}_{\mathrm{Sm}}
$$

where: $\mathrm{I}_{\mathrm{W}}=$ the growth index of $\mathrm{W} ; \mathrm{I}_{\mathrm{Sm}}=$ the growth index of the average salary.

Marginal productivity (Wm) is a complementary indicator that analyzes the efficiency of human resources, which is determined as a ratio between production growth and labor time variation, and shows us the effect of a spent supplementary unit of time.
$W m=\frac{\uparrow \Delta Q}{\Delta T}=\frac{\uparrow Q_{1}-Q_{0}}{T_{1}-T_{0}}$

$W m=\uparrow \frac{\Delta T}{\Delta Q}=\uparrow \frac{T_{1}-T_{0}}{Q_{1}-Q_{0}}$

A fundamental synthesizing indicator in categorizing the utilization of human resources is the elasticity of work (E). It makes a concret connection between Wm şi $\mathrm{W}$ :

$E=\frac{\Delta Q / Q}{\Delta T / T}=\frac{\Delta Q}{\Delta T} \times \frac{T}{Q}=\frac{\Delta Q}{\Delta T}: \frac{Q}{T}=W m: \bar{W}$

The elasticity calculated in this way signifies the rate of percentage increase of the activity volume, which has been determined by $1 \%$ of the human resource (time of work). Depending on the elasticity, the volume curve of the activity can be divided into three areas:

Area I: E > $\quad$ - we are in the area of increasing performance;

Area II: $\quad 0<\mathrm{E}<1 \quad$ - we are in the area of decreasing performance;

Area III: $\quad \mathrm{E}<0 \quad$ - we are in the area of negative performance.

The calculation can also be made on the basis of physical indicators:

$$
W=\frac{Q}{T} \quad W=\frac{T}{Q}
$$

where: Q - production obtained in physical expression; T - total time of work spent.

$W a=\frac{Q}{\overline{N p}} \quad W a=\frac{\overline{N p}}{Q}$

where: Q - physical production obtained in one year; $\overline{N p}=$ the average number of personnel.

$W z=\frac{Q}{\overline{N p} \times t z} \quad W z=\frac{\overline{N p} \times t z}{Q}$

where: Q - physical production obtained in one day.

$$
W h=\frac{Q}{\overline{N p} \times t z \times t h} \text { or } \quad W h=\frac{\overline{N p} \times t z \times t h}{Q}
$$


where: Q - physical production obtained in one hour.

Among the category of indicators that express the efficient use of human resources, an important place is occupied by the level of profit per employee. The analysis of this indicator is carried out on the basis of several factorial methods, taking into account the correlation that must be pursued between the degree of utilization of the human resources and the capacity of the production (the technical endowment of work).

A first model analyzing the profit per employee is the one that considers the profit/employee in relation to the production capacity:

$$
\frac{P}{\overline{N s}}=\frac{Q f}{\overline{N S}} \times \frac{C A}{Q f} \times \frac{P}{C A}=W a \times \frac{C A}{Q f} \times \overline{p r}
$$

where: Qf - manufactured goods destined for sales; $\overline{p r}$ - profit to 1 leu CA; $\bar{t}_{\text {- time }}$ expressed in hours; CA - turnover; Wa annual productivity; Wh - average hourly productivity; $\mathrm{CA} / \mathrm{Qf}$ - degree of capitalization of the manufactured goods (CA to 1 leu manufactured goods),

A second model of analysis is the following:

$$
\begin{gathered}
P / \overline{N S}=\frac{C A}{\overline{N S}} \times \frac{P}{C A}=W a \times \overline{p r} \\
\text { A third model refers to : } \\
\frac{P}{\overline{N S}}=\frac{T}{\overline{N S}} \times \frac{C A}{T} \times \frac{P}{C A}=\bar{t} \times \overline{W h} \times \overline{p r}
\end{gathered}
$$

where: T - total time of work; $\bar{t}$ - annual time of work spent/employee; $\mathrm{P} / \mathrm{CA}$ - profit that comes to 1 leu turnover.

The fourth factorial model is the one in which the volume of the fixed assets intervenes. This model establishes the correlation between profit/employee and the technical equipment:

$$
P / \overline{N s}=\frac{\overline{M f}}{\overline{N s}} \times \frac{\overline{M f}}{\overline{M f}} \times \frac{C A}{\overline{M f}}, \times \frac{P}{C A}=K t \times \frac{\overline{M f}}{\overline{M f}} \times \frac{C A}{\overline{M f}}, \times \overline{p r}
$$

where: $\overline{M f}$ - annual average value of fixed assets; $\overline{M f}$, - average value of directly productive fixed assets (or of active fixed assets); $\mathrm{Kt}$ - the technical endowment of work ; $\overline{M f}, / \overline{M f}$ the share of directly productive fixed assets in the total of fixed assets (the technical structure of capital); $\overline{M f}, / \overline{M f} ; \mathrm{CA} / \overline{M f}$, - efficiency of utilizing the directly productive fixed assets; $\overline{p r}$ average profit to 1 leu turnover.

Employee profit analysis establishes a correlation between the analysis of the efficiency of utilizing the work factor on the basis of productivity and cost effectiveness analysis. On the basis of the first model, the effect of modifying the degree of capitalization of the manufactured products can be highlighted, in order to establish measures that ensure the outlet of the manufactured goods and the diminution of the stored products. In the case of the fourth model, in addition it is highlighted the influence exerted by the modification of the degree of technical endowment of work, the technical composition of the fixed assets, as well as their cost effectiveness. With the help of this model, the correlation with the analysis of utilization of fixed assets is established.

\section{Case Study: Diagnostic Analysis of Construcţii SA}

\subsection{Short History}

CONSTRUCŢII SA operates as a joint stock company, based on Law no. 31/1990 on commercial companies, republished and completed with subsequent amendments.

The company has its headquarters in Sibiu, Morilor street, nr. 51, Sibiu county and the main object of activity is the execution of 
construction works of residential and nonresidential buildings, but also other activities specified in the constitutive act such as:

- construction works for industrial and commercial halls;

- road and highway works;

- electrical and telecommunication installations;

- sanitary, heating and air-conditioning installations;

- gas installation works;

- production of pre-cast reinforced concrete elements and pre-stressed concrete;

- manufacture of concrete and mortars;

- gravel and sand extraction and production of balestier natural aggregates.

The company operates in accordance with the rules of the Integrated Management System: quality, environment, occupational health and safety and is certified in accordance with international standards.
The majority shareholder of CONSTRUCTII SA is SINECON SA (included company), which owns $95 \%$ of the shares.

At the end of 2016, the General Shareholders' Meetings decided the merger by absorption of CONSTRUCTII SA Sibiu (absorbing company) with SINECON SA Sibiu (absorbed company). Thus, the SINECON SA Sibiu patrimony will be transmitted with assets and liabilities, receivables and debts, rights and obligations, as they are, to CONSTRUCTII SA Sibiu.

3.2. Average Personnel Number - the average personnel number in 2016 is 337.

This has declined by $1,78 \%$ as to the year 2017 when the average number was 343 employees. The average personnel number in 2018 is 276 . this has declined by $13,80 \%$ as to the year 2017 when the average number was 314 employees.

\begin{tabular}{|c|c|c|c|c|c|c|c|c|c|c|c|c|c|c|}
\hline & $\begin{array}{c}\text { Average } \\
\text { personnel } \\
\text { no. }\end{array}$ & Ian & Feb & Mar & Apr & May & Iune & Iul & Aug & Sep & Oct & Nov & Dec & average \\
\hline 1 & $\mathbf{2 0 1 7}$ & 205 & 240 & 316 & 354 & 378 & 383 & 382 & 392 & 396 & 401 & 387 & 291 & $\mathbf{3 4 3}$ \\
\hline 2 & $\mathbf{2 0 1 6}$ & 122 & 170 & 319 & 360 & 379 & 393 & 392 & 395 & 402 & 396 & 393 & 296 & $\mathbf{3 3 7}$ \\
\hline 3 & $\mathbf{2 0 1 7}$ & 308 & 310 & 316 & 316 & 313 & 314 & 317 & 316 & 316 & 314 & 315 & 312 & $\mathbf{3 1 4}$ \\
\hline 4 & $\mathbf{2 0 1 8}$ & 304 & 295 & 289 & 280 & 280 & 281 & 276 & 272 & 264 & 257 & 255 & 255 & $\mathbf{2 7 6}$ \\
\hline
\end{tabular}

The decline is significant in the months of January and February and is due to the measures taken by the executive management for the cold weather period, respectively the possibility for the directly productive personnel to benefit from the unemployment benefit during winter, in comparison with the previous year when the employees of the workshops in industry (prefabricated, reinforced, gravel, metallic, aluminum pvc) stayed employed in order to honor the orders with urgent deadlines.

3.3. Structure of the Personnel - by main categories of employees, the structure of the staff is as follows: 


\begin{tabular}{|c|c|c|c|c|}
\hline YEAR & $\mathbf{2 0 1 7}$ & $\mathbf{2 0 1 6}$ & $\mathbf{2 0 1 7}$ & $\mathbf{2 0 1 8}$ \\
\hline NUMBER OF STAFF - of which: & $\mathbf{4 2 0}$ & $\mathbf{4 4 1}$ & $\mathbf{3 1 4}$ & $\mathbf{2 7 6}$ \\
\hline A. CA members & $\mathbf{0}$ & $\mathbf{0}$ & $\mathbf{5}$ & $\mathbf{5}$ \\
\hline Contract mandate & 0 & 0 & $\mathbf{1}$ & $\mathbf{2}$ \\
\hline B. TESA staff & $\mathbf{8 5}$ & $\mathbf{8 9}$ & $\mathbf{7 7}$ & $\mathbf{8 7}$ \\
\hline of which: & & & & \\
\hline 1. with bachelor degrees: & 73 & 75 & $\mathbf{5 3}$ & $\mathbf{5 8}$ \\
\hline - engineers & 52 & 51 & 37 & 40 \\
\hline - economists & 11 & 13 & 9 & 12 \\
\hline - technicians & 6 & 6 & 5 & 4 \\
\hline - lawyers and other bachelor & & 5 & 1 & 2 \\
\hline degrees foremen/technicians & 3 & 4 & $\mathbf{8}$ & $\mathbf{9}$ \\
\hline 3. staff with highschool diploma & 5 & 5 & $\mathbf{7}$ & $\mathbf{8}$ \\
\hline 4. administrative staff & 4 & 5 & $\mathbf{5}$ & $\mathbf{4}$ \\
\hline 5. collaborators & $\mathbf{3 9}$ & $\mathbf{4 4}$ & $\mathbf{5}$ & $\boldsymbol{8}$ \\
\hline C. unskilled workers & $\mathbf{4 9}$ & $\mathbf{3 6}$ & $\mathbf{2 8}$ & $\mathbf{1 6}$ \\
\hline $\begin{array}{c}\text { D. indirectly productive workers } \\
\text { (guardians) }\end{array}$ & $\mathbf{4 8}$ & $\mathbf{4 9}$ & $\mathbf{2 9}$ & $\mathbf{8}$ \\
\hline E. skilled workers & $\mathbf{1 9 9}$ & $\mathbf{2 2 3}$ & $\mathbf{1 7 4}$ & $\mathbf{1 5 8}$ \\
\hline
\end{tabular}

The actual number of employees increased in 2016 by 21 employees, i.e. 5\% compared to 2015. This is due to the increase in the volume of work following the contracting of new works.

The age structure of the staff in the analyzed period is balanced, the company having both young staff and highly experienced staff and this balance being kept from year to year.

The average age for all newly-employed staff in 2016 is 41 years.

The number of qualified staff rose by $12 \%$ in 2016, while the number of unqualified staff decreased by $36 \%$.

In the calculation of the number of employees, there were included all employees with individual labor contracts concluded for a definite or indefinite period of time, the employees with part-time contracts included.

The number of employees decreased by 38 employees $(13.80 \%)$ in 2018 compared to 2017. This is due to the termination of contractual relations with certain employees within the company. Thus, starting with February 2018, two teams of workers from the Vâlcea County, who have found work near home, a team of Sibiu carpenters, four workers from Moldova, seven plumbers, three project managers, 8 engineers, 3 lawyers and 3 economists left the organization.

The decrease in the number of staff is also due to the outsourcing of security at the construction sites.

However, there is an increase in the number of TESA staff in 2017, this increase being influenced by staff recruitments during the year, in order to fill vacancies: economic department $=2$ persons, execution engineers $=7$ persons (Feteşti included), technical service $=3$ persons, legal/eligibility $=2$ persons, directly productive staff $=72$ persons, etc.

The age structure of the staff during the analyzed period is balanced, with the 
company having both young staff and experienced staff and this balance being kept from year to year.

\subsection{Situation Regarding the Time Worked under the Normal Work Schedule}

\begin{tabular}{|c|c|c|c|c|}
\hline \multirow{2}{*}{ Number of worked hours } & \multicolumn{2}{|c|}{2016} & \multicolumn{2}{|c|}{2015} \\
\hline & Hours & Days & Hours & Days \\
\hline $\begin{array}{l}\text { Time worked under the normal work } \\
\text { schedule }\end{array}$ & 621.213 & & 631.238 & \\
\hline $\begin{array}{l}\text { Time worked under the normal work } \\
\text { schedule/person }\end{array}$ & 1.843 & & 1.840 & \\
\hline $\begin{array}{l}\text { Time worked under the supplementary } \\
\text { work schedule }\end{array}$ & 65.315 & & 70.632 & \\
\hline $\begin{array}{l}\text { Time worked under the supplementary } \\
\text { work schedule/person }\end{array}$ & 194 & & 206 & \\
\hline No. of days worked & & 85.055 & & 85.880 \\
\hline No. of days worked/person & & 252 & & 250 \\
\hline$(\%) 2016 / 2015$ - hours & & & $99,50 \%$ & \\
\hline (\%) 2016/2015 - days & & & & $99,00 \%$ \\
\hline
\end{tabular}

\begin{tabular}{|c|c|c|c|c|}
\hline \multirow[t]{2}{*}{ Number of worked hours } & \multicolumn{2}{|c|}{$\begin{array}{c}2018 \\
\text { average no. }=276\end{array}$} & \multicolumn{2}{|c|}{ 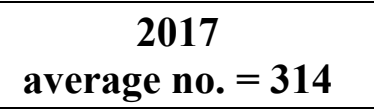 } \\
\hline & Hours & Days & Hours & Days \\
\hline $\begin{array}{l}\text { Time worked under the normal work } \\
\text { schedule }\end{array}$ & 488.972 & & 565.570 & \\
\hline $\begin{array}{l}\text { Time worked under the normal work } \\
\text { schedule/person }\end{array}$ & 1.771 & & 1.801 & \\
\hline $\begin{array}{l}\text { Time worked under the supplementary } \\
\text { work schedule }\end{array}$ & 51.171 & & 34.457 & \\
\hline $\begin{array}{l}\text { Time worked under the supplementary } \\
\text { work schedule/person }\end{array}$ & 185 & & 109 & \\
\hline No. of days worked & & 62.349 & & 71.679 \\
\hline No. of days worked/person & & 226 & & 228 \\
\hline (\%) 2018/2017 - hours & & & $98,33 \%$ & \\
\hline (\%) 2018/2017 - days & & & & $99,12 \%$ \\
\hline
\end{tabular}

There is a constant value of the number of hours worked and of the number of days worked in 2016 compared to the previous year.

There is an approximately equal value of the number of hours worked and the number of days worked in 2018 as compared to the previous year, relative to the number of staff.

3.5. Situation Regarding Not-Worked Time under the Normal Work Schedule the not-worked time is structured in:

- paid not-worked time;

- unpaid not-worked time. 
The unpaid not-worked time represents paid time, but during which the employees did not carry out any activity for various reasons, such as:

a) medical leaves - cases of sickness, temporary disability, maternity, accidents at work or occupational diseases; b) rest leaves;

c) other paid days, according to the Collective Labor Agreement and the legislation in force.

\begin{tabular}{|l|c|c|c|}
\hline \multicolumn{1}{|c|}{ Indicators } & $\mathbf{2 0 1 6}$ & $\mathbf{2 0 1 5}$ & $\mathbf{2 0 1 6 / 2 0 1 5}(\mathbf{\% )}$ \\
\hline Number of days ML & 1.023 & 1.115 & $91,70 \%$ \\
\hline Allowances for ML (Lei) & 73.744 & 78.211 & $94,30 \%$ \\
\hline Average script number & 337 & 343 & $98,30 \%$ \\
\hline $\begin{array}{l}\text { Number of employees with sick } \\
\text { leave }\end{array}$ & 111 & 119 & $93,30 \%$ \\
\hline $\begin{array}{l}\text { Number of days ML/Average } \\
\text { number of employees }\end{array}$ & 3,03 & 3,25 & $93,20 \%$ \\
\hline $\begin{array}{l}\text { No. of days ML/No.of employees } \\
\text { with ML }\end{array}$ & 9,21 & 9,37 & $98,30 \%$ \\
\hline
\end{tabular}

From the analysis of the medical leaves in 2016 as compared to the year 2015, the following conclusions can be drawn:

- the number of days of sick leave decreased in 2016 compared to 2015 by $8.3 \%$;

- he allowances for medical leave in 2016 compared to 2015 decreased by 4,467 lei, i.e. by $5.5 \%$.

- the number of employees who had sick leave decreased by $6.7 \%$ from 119 in 2015 to 111 in 2016.

The decrease in the number of employees on sick leave is due in the first place to the tightening of the legislation on the issue of medical certificates by doctors.

Another reason for diminishing the number of medical leaves compared to the previous years is the fact that during the years 20152016 there were no work accidents.

In 2016 medical leaves represent 3.03 days/average number and 9.21 days/number of employees on ML compared to 2015 when medical leaves represent 3.25 days/average number and 9.37 days/number of employees on ML.

\begin{tabular}{|l|c|c|c|}
\hline \multicolumn{1}{|c|}{ Indicators } & $\mathbf{2 0 1 8}$ & $\mathbf{2 0 1 7}$ & $\begin{array}{c}\mathbf{2 0 1 8 / 2 0 7 5} \\
\mathbf{( \% )}\end{array}$ \\
\hline Number of days ML & 1.725 & 1.504 & $114,69 \%$ \\
\hline Allowances for ML (Lei) & 161.480 & 135.371 & $119,29 \%$ \\
\hline Average script number & 276 & 314 & $87,90 \%$ \\
\hline No. days ML/Average no. employees & 6,25 & 4,79 & $130,49 \%$ \\
\hline
\end{tabular}

From the analysis of the medical leaves in 2018 as against the year 2017, the following conclusions can be drawn:

- the number of days of sick leave increased in 2018 compared to 2017 by $14.69 \%$;
- allowances for medical leave in 2018 compared to 2017 increased by 26,109 lei, i. e. by $19.29 \%$;

- in 2018 medical leaves represent 6.25 days/average number, compared to 2017 
when medical leaves are 4.79 days/average number.

The most common diagnoses for employees who benefited from medical leave in 2018 and 2017 are: viruses and pneumonia (early in the year), back pains, hernias and fractures of the lower limbs that required 2-3 months immobilization.

Rest leaves - throughout the period 20152018, rest leave was granted proportionally to the period worked, with days of leave diminishing in proportion to the period actually worked (days of sick leave, unpaid leave, leaves and unjustified absences). During the whole period, as in the previous years, holiday leaves were not entirely carried out according to the schedule made at the beginning of the year, which led to the fact that at the beginning of December 2016 there were a number of 2,198 days of not spent leave, which represents $34,10 \%$ of the total number of 2016 days compared to 2015 when at the beginning of December we had 2,448 days of not spent leave, i.e. 37,30\%.

At the beginning of December 2018, we had a number of 1,751 days of not spent leave, which represents $27.61 \%$ of the total number of days related to 2018 compared to 2017 when at the beginning of December we had a number of 2,460 days of not spent leave, i.e. $3782 \%$.

\begin{tabular}{|c|c|c|c|c|}
\hline Year & Days due & $\begin{array}{c}\text { Days carried } \\
\text { out Jan-Nov. }\end{array}$ & $\begin{array}{c}\text { Days to be } \\
\text { carried out in } \\
\text { Dec. }\end{array}$ & $\%$ \\
\hline $\mathbf{2 0 1 8}$ & 6.171 & 4.483 & 1.688 & $27,35 \%$ \\
\hline $\mathbf{2 0 1 7}$ & 6.879 & 4.524 & 2.355 & $34,23 \%$ \\
\hline $\mathbf{2 0 1 6}$ & 6.450 & 4.372 & 2.198 & $34,1 \%$ \\
\hline $\mathbf{2 0 1 5}$ & 6.560 & 4.112 & 2.448 & $37,3 \%$ \\
\hline
\end{tabular}

Valorically, the situation is as follows:

\begin{tabular}{|l|l|l|l|l|l|l|}
\hline Year & $\begin{array}{c}\text { Days } \\
\text { due }\end{array}$ & Value & $\begin{array}{c}\text { Days } \\
\text { carried } \\
\text { out Jan- } \\
\text { Nov. }\end{array}$ & Value & $\begin{array}{c}\text { Days to be } \\
\text { carried out } \\
\text { in Dec. }\end{array}$ & Value \\
\hline $\mathbf{2 0 1 8}$ & 6.171 & $\mathbf{1 . 3 8 9 . 0 2 9}$ & 4.483 & $\mathbf{1 . 0 0 9 . 0 7 7}$ & 1.688 & $\mathbf{3 7 9 . 9 5 2}$ \\
\hline $\mathbf{2 0 1 7}$ & 6.879 & $\mathbf{1 . 2 0 2 . 9 8 1}$ & 4.524 & $\mathbf{7 9 1 . 1 4 5}$ & 2.355 & $\mathbf{4 1 1 . 8 3 6}$ \\
\hline $\mathbf{2 0 1 6}$ & 6.450 & $\mathbf{7 6 0 . 3 5 6}$ & 4.372 & $\mathbf{5 1 5 . 3 9 2}$ & 2.198 & $\mathbf{2 4 4 . 9 6 4}$ \\
\hline $\mathbf{2 0 1 5}$ & 6.560 & $\mathbf{7 3 9 . 4 2 4}$ & 4.112 & $\mathbf{4 6 3 . 4 9 3}$ & 2.448 & $\mathbf{2 7 5 . 9 3 1}$ \\
\hline
\end{tabular}

In 2016, the number of holiday days in December (during the month or after the end of activity) is 1.876, which represents $29.08 \%$ of the total number of days for 2016, with 322 not spent days, i.e. $4.99 \%$. Out of the 322 not spent days, a total of 219 days was compensated in cash for the employees who during the year reserved 10 days of leave for the period of discontinuation of activity or did not go on holiday at the request of the management according to the schedule, finally having 103 days of unpaid and not carried out leave, i.e. $2.98 \%$ of the total days of holiday in 2016.

In 2015, the number of holidays in December (after the end of activity) was 2,209 , which represents $33.67 \%$ of the total number of days for 2015, leaving 239 not spent days, i.e. $6.64 \%$. Of the 239 not spent 
days, a total of 156 days was compensated in cash for the employees who made holiday requests during the year and for objective reasons were not granted, leaving a number of 83 unpaid and not carried out days of leave, i.e. $1.26 \%$ of the total days of holiday in 2015.

In 2018, the number of leave days in December (during the month or after the end of activity) was 1.142 , which is $18.50 \%$ of the total number of days for 2018, with 546 not spent days, i.e. $8.85 \%$.

The remaining 546 days were compensated by the employees' payment, some of them demanding these days during the year, or did not leave on leave according to the schedule, at the request of the management.

In 2017, the number of leave days that took place in December (during the month or after the end of activity) was 1,340, which represents $19.48 \%$ of the total number of days for 2017 , with 1,015 not spent days, i.e. $14.75 \%$.
Of the remaining 1,015 days, 545 days were compensated in cash for the employees who made holiday requests during the year and for objective reasons they were not approved, while 470 remained unpaid and not spent days of leave which were reported to 2018 and were carried out by the employees concerned within the first part of the year.

In recent years, rest leaves were insisted on being taken strictly in accordance with the schedule, thus significantly reducing the number of not spent days at the end of the year.

Other paid leave days - were granted according to the Collective Labor Agreement for special events in the following situations: the employee' marriage, the marriage of the employee's children, the death of a first or nextgeneration relative, blood donors, etc.

\begin{tabular}{|c|l|l|l|l|l|l|l|l|l|l|l|l|c|}
\hline $\begin{array}{c}\text { Days } \\
\text { Ev. }\end{array}$ & Ian & Feb & Mar & Apr & May & Iun & Iul & Aug & Sep & Oct & Nov & Dec & Total \\
\hline $\mathbf{2 0 1 8}$ & 10 & 0 & 10 & 11 & 22 & 8 & 15 & 9 & 25 & 2 & 6 & 0 & $\mathbf{1 1 8}$ \\
\hline $\mathbf{2 0 1 7}$ & 3 & 9 & 6 & 4 & 13 & 3 & 0 & 6 & 17 & 7 & 3 & 11 & $\mathbf{8 2}$ \\
\hline $\mathbf{2 0 1 6}$ & 0 & 3 & 3 & 3 & 8 & 13 & 5 & 7 & 9 & 6 & 1 & 1 & $\mathbf{5 9}$ \\
\hline $\mathbf{2 0 1 5}$ & 0 & 11 & 0 & 1 & 8 & 16 & 0 & 17 & 11 & 12 & 8 & 2 & $\mathbf{9 2}$ \\
\hline
\end{tabular}

Granting these days was made on the basis of a request to which the evidence was attached, as the case may be (birth certificate, marriage, death, blood donation certificate, etc.)

Unpaid non-worked time includes:

- unmotivated absences.

In the year 2016, of the total unpaid working time, 1,992 days were unpaid holidays, most of which were carried out by employees who have their domicile in other localities and who every 2-3 weeks visit their family and ask for unpaid holidays.

Also, in December, a large number of employees had to take unpaid leave because the period of interruption of their activity could not be fully covered by days of rest leave 


\begin{tabular}{|c|l|l|l|l|l|l|l|l|l|l|l|l|l|}
\hline $\begin{array}{c}\text { Days } \\
\text { UWT }\end{array}$ & Ian & Feb & Mar & Apr & Mai & Iun & Iul & Aug & Sep & Oct & Nov & Dec & Total \\
\hline $\mathbf{2 0 1 8}$ & 723 & 166 & 116 & 77 & 112 & 101 & 152 & 145 & 153 & 76 & 62 & 343 & $\mathbf{2 . 2 2 6}$ \\
\hline $\mathbf{2 0 1 7}$ & 583 & 342 & 203 & 150 & 95 & 93 & 92 & 104 & 132 & 122 & 110 & 417 & $\mathbf{2 . 4 4 3}$ \\
\hline $\mathbf{2 0 1 6}$ & 223 & 106 & 49 & 101 & 96 & 143 & 174 & 157 & 192 & 203 & 184 & 354 & $\mathbf{1 . 9 9 2}$ \\
\hline $\mathbf{2 0 1 5}$ & 101 & 126 & 49 & 128 & 296 & 298 & 272 & 176 & 110 & 199 & 137 & 302 & $\mathbf{2 . 2 8 3}$ \\
\hline
\end{tabular}

3.6. Situation Regarding Labor Productivity

The analysis was carried out only for the period 2017-2018, as we did not have access to all the data necessary for its realisation for the period 2015-2016.

The calculation of labor productivity at Constructions SA in 2017 compared to 2018 is as follows:

\begin{tabular}{|c|c|c|c|c|}
\hline INDICATOR & SYMBOL & 2018 & 2017 & $\%$ \\
\hline Turnover & CA & $121,613,131$ & $115,067,769$ & $105.69 \%$ \\
\hline $\begin{array}{c}\text { Average number of } \\
\text { employees }\end{array}$ & Np & 276 & 314 & $87.90 \%$ \\
\hline $\begin{array}{c}\text { Average number of days } \\
\text { worked by } 1 \text { employee in } \\
\text { a year }\end{array}$ & $\mathrm{Nz}$ & 226 & 228 & $99.12 \%$ \\
\hline $\begin{array}{l}\text { Average number of hours } \\
\text { in a day of work }\end{array}$ & tz & 8 & 8 & $100.00 \%$ \\
\hline $\begin{array}{l}\text { Total fund of time of } \\
\text { work (days-person) }\end{array}$ & $\mathrm{Nh}$ & 62,376 & 71,592 & $87.13 \%$ \\
\hline $\begin{array}{l}\text { Total fund of time of } \\
\text { work (days-person) }\end{array}$ & th & 499,008 & 572,736 & $87.13 \%$ \\
\hline $\begin{array}{l}\text { Annual average } \\
\text { productivity } \\
\text { (lei) }\end{array}$ & $\begin{array}{l}W a= \\
C A / p\end{array}$ & 440,627 & 366,458 & $120.24 \%$ \\
\hline $\begin{array}{c}\text { Daily average } \\
\text { productivity } \\
\text { (lei) }=\text { CA/fund of time } \\
\text { (days-person) }\end{array}$ & $\begin{array}{l}W z= \\
C A / t z\end{array}$ & 1,950 & 1,607 & $120.24 \%$ \\
\hline $\begin{array}{l}\text { Daily average } \\
\text { productivity } \\
\text { (lei) }=\text { CA/fund of time } \\
\text { (hours-person) }\end{array}$ & $\begin{array}{l}\text { Wh= } \\
\mathrm{CA} / \text { th }\end{array}$ & 244 & 201 & $121.30 \%$ \\
\hline
\end{tabular}

Source: Own calculations

$\Delta W a=W a 1-W a 0=440,627-366,456=$ 74,169

of which:

$\Delta W a(N z)=(N z 1-N z 0) * W z 0=(-2) *$ $1,607=-3,215$ that is, productivity decreased by 3,214 lei due to the average number of days worked by 1 employee in a year $(\mathrm{Nz})$, and $\Delta W a(W z)=N z 1 *(W z 1-W z 0)=226 *$ $343=77,384$

that is, productivity increased by 77,518 lei due to the increase in average daily productivity $(\mathrm{Wz})$. 
Equality check:

$\Delta W a=\Delta W a(N z)+\Delta W a(W z)$

$74,169=77,384-3,215$

\subsection{Analysis of Profit Per Employee}

From the category of indicators that express the efficient use of human resources, an important place occupies the level of profit per employee.

The analysis of this indicator is based on several factorial methods, taking into account the correlation to be observed between the degree of human resource use and the production capacity (technical endowment of labor).

\begin{tabular}{|c|c|c|c|c|c|}
\hline INDICATOR & SYMBOL & 2018 & 2017 & $\%$ & $\Delta$ \\
\hline Turnover & $C A$ & $121,613,131$ & $115,067,769$ & $105.69 \%$ & $6,545,362$ \\
\hline $\begin{array}{l}\text { Manufactured goods } \\
\text { destined for sale }\end{array}$ & $Q f$ & $119,880,111$ & $111,503,118$ & $107.51 \%$ & $8,376,993$ \\
\hline $\begin{array}{l}\text { Average number of } \\
\text { employees }\end{array}$ & $N p$ & 276 & 314 & $87.90 \%$ & -38 \\
\hline Resulting net profit & $P$ & $4,205,171$ & $3,245,253$ & $129.58 \%$ & 959,918 \\
\hline $\begin{array}{l}\text { Annual average } \\
\text { Productivity (lei) }\end{array}$ & $\begin{array}{l}W a= \\
C A / p\end{array}$ & 440,627 & 366,458 & $120.24 \%$ & 74,169 \\
\hline Profit to 1 leu CA & $P / C A$ & 0.0346 & 0.0282 & $122.61 \%$ & 0 \\
\hline Total time of work & $T$ & 540,143 & 600,027 & $90.02 \%$ & $-59,884$ \\
\hline $\begin{array}{l}\text { Annual time of work } \\
\text { spent/employee }\end{array}$ & $t$ & 1,957 & 1,911 & $102.41 \%$ & 46 \\
\hline $\begin{array}{l}\text { Hourly average } \\
\text { productivity }\end{array}$ & $W h=C A / t h$ & 225 & 192 & $117.41 \%$ & 33 \\
\hline $\begin{array}{l}\text { Profit per } \\
\text { employee - lei }\end{array}$ & $\frac{P}{\overline{N S}}=\frac{Q f}{\overline{N S}} \times \frac{C A}{Q f} \times \frac{P}{C A}=W a \times \frac{C A}{Q f}$ & 15,236 & 10,335 & $147.42 \%$ & 4,901 \\
\hline $\begin{array}{l}\text { Profit per } \\
\text { employee - lei }\end{array}$ & $P / \overline{N S}=\frac{C A}{\overline{N S}} \times \frac{P}{C A}=W a \times$ & 15,236 & 10,335 & $147.42 \%$ & 4,901 \\
\hline $\begin{array}{l}\text { Profit per } \\
\text { employee - lei }\end{array}$ & $\frac{P}{\overline{N S}}=\frac{T}{\overline{N S}} \times \frac{C A}{T} \times \frac{P}{C A}=\bar{t} \times \overline{W h}$ & 15,236 & 10,335 & $147.42 \%$ & 4,901 \\
\hline
\end{tabular}

\section{References}

[1] Cindrea, I., Managementul resurselor umane, "Lucian Blaga" University of Sibiu Publishing House, 2008, p.8.

[2] Buşe, L., Siminică, M., Cârciumaru, D., \& Marcu, N., Analiză economico-financiară, Sitech Publishing House, Craiova, 2007, p. 62.

[3] Gheorghiu, Al., Analiza economico-financiară la nivel microeconomic, Economic Publishing House, Bucharest, 2004, p. 39.

[4] Rosca, C., Resurse umane, Universitaria Publishing House, Craiova, 2005, p. 41.

[5] Radu, C., Georgescu V., \& Ionaşcu C., Statistica firmei, Universitaria Publishing House, Craiova 2004, p. 57.

[6] Ibidem p. 58.

[7] Ibidem p. 60.

[8] Ibidem p. 61.

[9] Ibidem p. 62.

[10] Ibidem p. 8. 